\title{
Serological and virological profile of patients with chronic hepatitis $B$ infection in Eritrea
}

\section{Mohammed Elfatih Hamida ${ }^{1 *}$, Saud Mohammed Raja², Yemane Seyoum², Isam Mohammed Elkhidir ${ }^{3}$ and Freweini Tekle $^{4}$}

${ }^{1}$ Orotta College of Medicine and Health Sciences, Department of Microbiology, Asmara, Eritrea ${ }^{2}$ Orotta College of Medicine and Health Sciences, Department of Internal Medicine, Asmara, Eritrea

${ }^{3}$ University of Khartoum, Faculty of Medicine, Department of Microbiology, Khartoum, Sudan ${ }^{4}$ Ministry of Health, National Health Laboratory, Asmara, Eritrea

\section{Abstract}

Background: Hepatitis B virus infection is a major cause of liver associated morbidity and mortality with diverse spectrum of disease. It is estimated about $15 \%$ to $40 \%$ of patients with hepatitis $B$ virus infection progress to chronic hepatitis and about $15 \%$ to $25 \%$ die from disease complications. The main aim of this study was to evaluate the serological and virological markers of patients with chronic hepatitis $B$ virus infection to determine the natural history of chronic hepatitis B infection in the Eritrean setting.

Methods: A laboratory-based cross-sectional study was conducted on 305 patients with $\mathrm{HBsAg}$ positive who presented to Orotta National Referral Hospital, Halibet Hospital, Sembel Hospital and National Health Laboratory in Asmara, Eritrea from January 2017 to February 2019. Enzyme-linked immunosorbent assay was performed to detect hepatitis B serological markers (anti-HBc, $\mathrm{HBsAg}$, anti-HBsAb, HBeAg and anti-HBeAg). Hepatitis B DNA viral loads and liver transaminase levels were determined. Data analysis was conducted using SPSS version 25.0.

Results: A total of 305 patients presented with HBsAg positive serology with a mean age of 41.3 ( \pm 13.7 ) years ranging from 16 to 78 years. Males were $218(71.5 \%)$ and females $87(28.5 \%)$.Anti-HBc was positive in 300 (98.4\%), of which 293 (97.5\%) were positive for HBsAg and $7(2.3 \%)$ positive for anti-HBs. Among these 293 patients, 20 (6.8\%) were HBeAg positive/anti-HBe positive, $242(82.6 \%)$ $\mathrm{HBeAg}$-negative/anti-HBe-positive and $31(10.6 \%)$ were $\mathrm{HBeAg}$ negative/anti-HBe-positive. Detectable HBV DNA was found in 122(41.6\%) of the 293 cases. Alanine transaminase was normal in $90 \%$ of HBeAg-positive and in $91.2 \%$ of HBeAg-negative patients. Hepatitis B DNA viral load was $>2,000$ IU/ $\mathrm{mL}$ in $67(22.86 \%)$ and $>200,000 \mathrm{IU} / \mathrm{mL}$ level was more frequently detected in HBeAg positive $(20.0 \%)$ compared to HBeAg negative $(1.8 \%)$ subjects $(p<0.001)$.

Conclusion: This study shows predominance of HBeAg-negative and low replication phase of HBV infection among patients in Eritrea. It also documented that most patients had chronic infection with normal liver transaminase levels in the absence of biochemical signs of hepatitis. This study will provide a basis for therapeutic evaluation of patients and planning national treatment guidelines in the Eritrean setting.

\section{More Information}

*Address for Correspondence: Mohammed Elfatih, Orotta College of Medicine and Health Sciences, Department of Microbiology, Asmara, Eritrea, Email: mohelfatih77@gmail.com

Submitted: 17 July 2020

Approved: 23 July 2020

Published: 24 July 2020

How to cite this article: Hamida ME, Raja SM, Seyoum Y, Elkhidir IM, Tekle F. Serological and virological profile of patients with chronic hepatitis B infection in Eritrea. Int J Clin Virol. 2020; 4: 096-101.

\section{DOI: 10.29328/journal.ijcv.1001022}

Copyright: @ 2020 Hamida ME, et al. This is an open access article distributed under the Creative Commons Attribution License, which permits unrestricted use, distribution, and reproduction in any medium, provided the original work is properly cited.

Keyword: Hepatitis B virus (HBV); Chronic Hepatitis B (CHB); Natural history; HBV DNA viral load; Low replicative phase; ELISA; PCR

Abbreviations: ALT: Alanine Aminotransferase; Anti-Hbc: Antibody to Hepatitis B Core Anti- Gen; Anti-Hbs: Hepatitis B Surface Antibody; AST: Aspartate Transaminase; CHB: Chronic Hepatitis B; ELISA: Enzyme-Linked Immunosorbent Assay; Hbeag: Hepatitis B E Antigen; Hbsag: Hepatitis B Surface Antigen; HBV: Hepatitis B Virus; HCC: Hepatocellular Carcinoma; IQR: Interquartile Range; LC: Liver Cirrhosis; M: Mean; Md: Median; Min.: Minimum, Max.: MaxiMum; NHL: National Health Laboratory; OCMHS: College of Medicine and Health Sciences; SD: Standard Deviation; WHO: World Health Organization

\section{(D) Check for updates}

(1) OPEn AcCess

\section{Background}

Hepatitis B virus (HBV) infection is a major global public health threat especially in developing countries. The World Health Organization (WHO) estimates that in 2015, about 60 million Africans were living with chronic HBV infection [1]. Most African countries fall within the high endemicity regions [2]. Infection with HBV is usually acquired through perinatal or childhood exposure to the virus, contaminated blood transfusions or unprotected sexual contact [3] and progresses to long-term HBV infection in about $15 \%$ to $40 \%$ of cases depending on viral and host factors [4,5]. Although chronic HBV infection is commonly asymptomatic, an estimated $15 \%$ to $25 \%$ of patients will die from disease progression and complication such as liver cirrhosis (LC) and hepatocellular carcinoma (HCC)[4]. 
The natural history of chronic HBV infection is categorized into five clinical phases according to Hepatitis B e Antigen (HBeAg), HBV DNA levels, alanine aminotransferase (ALT) and liver inflammation status. These are (1) immune tolerant HBeAg positive phase, which progresses to (2) immunereactive $\mathrm{HBeAg}$-positive phase, (3) inactive $\mathrm{HBV}$ carrier state (HBeAg negative) phase, (4) HBeAg-negative chronic hepatitis $\mathrm{B}$ (CHB) phase and (5) HBsAg negative phase [6,7]. However, not all chronically infected patients go through all these phases and the phases vary in duration. It is quite a complex process and is difficult to distinguish between these phases in clinical practice [8]. Therefore, different periodic studies for HBV serological and viral markers studies are required to assess treatment requirement.

Patients with HBV infection should be screened serologically to determine whether they have chronic infection or had suffered previous exposure to HBV. To that ends, it is necessary to test the serum for hepatitis B surface antigen (HBsAg), hepatitis B surface antibody (anti-HBs), and antibody to hepatitis B core antigen (anti-HBc) [9].

The quantification of HBV DNA (viral load) level is the most reliable virological marker to determine active HBV replication and, in combination with liver enzymes and clinical assessment, it enables accurate evaluation of natural history of hepatitis $\mathrm{B}$, as well as the risk of disease progression among HBV infected patients [10-12]. Therefore, understanding of these markers is quite crucial in monitoring the disease progression and optimal management of patients [13].

Eritrea is geographically located in sub-Saharan Africa, a region considered endemic to $\mathrm{HBV}$ infection with an intermediate to high prevalence [1]. The epidemiology of HBV infection in Eritrea is not well documented and there are only limited studies conducted to explore the extent of the problem. Available HBV infection prevalence data from previous studies conducted reported an intermediate prevalence of HBsAg seromarkers of $2.6 \%$ to $3.2 \%[14,15]$. However, the limited of availability of the serological and molecular testing constitutes one of the most important barriers for obtaining a clearer picture. These drawbacks pose a challenge for clinicians in determining the exact clinical stage of HBV infected patients and assessment of requirement for treatment. Such barriers in resource limited countries may hinder the attainment of global viral hepatitis control [1]. We performed this study to determine HBV serological and virological markers to investigate the natural history of $\mathrm{CHB}$ infection among Eritrean patients.

\section{Method and materials}

\section{Study design and setting}

A laboratory-based cross-sectional study was conducted among 305 patients with seropositivity for HBsAg attending to the hepatology units and outpatient clinics of Orotta
National Referral Hospital, Halibet Hospital, Sembel Hospital and National Health Laboratory (NHL) in Asmara, Eritrea, between January 2017 and February 2019. Patients with acute hepatitis and blood donors who tested positive for HBsAg were not included in the study.

\section{Specimen's collection}

Venous blood ( $5 \mathrm{ml}$ ) was collected aseptically by a trained phlebotomist into a dry tube. The sample was then centrifuged at $3000 \mathrm{rpm}$ for 5 minutes at room temperature to obtain serum that was divided into two cryogenic tubes - one for serology and biochemistry and the second for molecular testing kept frozen at $-20{ }^{\circ} \mathrm{C}$ until testing.

\section{Serological tests}

Serological markers for hepatitis B virus (anti-HBc total, HBsAg, anti-HBsAg HBeAg and anti-HBeAg) were performed by using commercial enzyme-linked immunosorbent assay (ELISA) in vitro diagnostic kits (Fortress Diagnostics, United Kingdom). The concentration of the specific antibody-antigen complex in the specimen was determined by means of a cut-off value according to the procedures described by the manufacturers. In addition, positive and negative controls were run simultaneously to check the validity of test. All patients were tested for antibody to HBV core antigen (anti$\mathrm{HBc}$ ) total. Those with detectable anti-HBc were tested for HBV surface antigen (HBsAg) and antibody to HBV surface antigen (anti-HBs). Those with detectable antibody to HBV core antigen (anti-HBc) and HBV surface antigen (HBsAg) were tested for hepatitis B ' $\mathrm{e}$ ' antigen (HBeAg) as well as antibody to hepatitis B 'e' antigen (anti-HBe). All specimens with positive HBsAg and positive for anti-HBc were further processed for quantitative HBV DNA viral load.

\section{Biochemistry}

Serum liver transaminase levels, alanine transaminase (ALT) and aspartate transaminase (AST), were measured by using automated clinical chemistry analyzer (Beckman coulter au480, USA) following the manufacturer's instructions, in accordance with principle based on International federation of clinical chemistry and quality control measures. The normal reference value for ALT and AST were considered as $<40 \mathrm{U} / \mathrm{l}[16]$.

\section{HBV viral load quantification}

Quantitative detection of HBV DNA (viral load) in serum of CHB patients was measured using COBAS AmpliPrep/ COBAS TaqMan 48HBV Test, version 2.0 (Roche Diagnostics, Switzerland) for automated amplification and detection of a limit between 20 to 170,000,000 IU/mL. Specimen preparation and simultaneous polymerase chain reaction (PCR) amplification of target DNA was done followed by detection of cleaved dual-labelled oligonucleotide detection probe specific to the target according to the manufacturer's 
instructions. HBV viral load quantitative level exceeding 2,000 IU/mL was considered a high-level HBV replication whereas below 2,000 IU/mL as low-level replication [12]. An undetectable viral load was defined as HBV DNA below the level of sensitivity of the assay $(<20 \mathrm{IU} / \mathrm{mL})$.

\section{Statistical analysis}

Data were analyzed using SPSS (Statistical Package for the Social Sciences) version 25.0 (IBM; Chicago, IL, USA) and the values were represented in numbers, percentages and mean \pm standard deviation (SD). Statistical analyses for categorical variable were performed to determine test of significance. A $p$ value $<0.05$ was considered as statistically significant.

\section{Ethical approval and consent}

Ethical approval for this study was obtained from ethical research committee board of Orotta College of Medicine and Health Sciences (OCMHS) and Ministry of Health state of Eritrea (MoH). A written informed consent was obtained from each study participant before collecting the demographic and clinical data.

\section{Results}

\section{Socio-demographic characteristics}

Of the 305 patients who presented with a positive HBsAg serum, 218 (71.5\%) were males and 87 (28.5\%) were females. Mean age \pm standard deviation (SD) was $41.39 \pm 13.77$ years ranging from 16 to 78 years old. Most (27.0\%)of the participants were in the age group of 41- 50 years, followed by equal distribution of 51 and above group and 31-40 years' group were $(23.5 \%$ each). Most $(70.8 \%)$ of the participants were married. The majority (39.0\%) of participants were government employees followed by nearly equal distribution of private workers (27.5\%) and unemployed (26.9\%). Almost half of the patients (49.8\%) hailed from Zoba Maekel, the central region of the country where the hospitals in this study and the national health laboratory are located. All these characteristics and distributions by gender are as shown in table 1.

\section{HBV serology}

With the exception of 5 cases, 300 (98.4\%) out of the 305 initially positive for HBsAg were found to have positive anti$\mathrm{HBc}$ total. Out of the 300 total anti-HBc positive, $97.7 \%$ had positive HBsAg with $2.3 \%$ having positive anti-HBsAg. From the total 305 of HBV patients, the percentage of anti-HBc total positive/HBsAg-positive was found to be 96.1\%. Further investigation of those anti-HBc total positive/HBsAg-positive $(n=293)$ revealed that the percentage of $\mathrm{HBeAg}$ positive/ anti-HBeAg negative, anti-HBeAg positive/HBeAg-negative and both $\mathrm{HBeAg}$ negative/anti-HBeAg negative were $6.8 \%$, $82.6 \%$ and $10.6 \%$ respectively. Overall, HBeAg was detected in $6.8 \%(20 / 293)$ of patients, anti-HBe was positive in $82 \%$ (242/293) (Figure 1). There was no statistically significant
Table 1: Socio-demographic characteristics of HBV infected patients $(n=305)$.

\begin{tabular}{|c|c|c|c|}
\hline \multirow{2}{*}{ Variable } & \multicolumn{2}{|c|}{ Gender* } & \multirow{2}{*}{$\begin{array}{c}\text { Total }^{* *} \\
n(\%)\end{array}$} \\
\hline & Male $n(\%)$ & Female $n(\%)$ & \\
\hline \multicolumn{4}{|c|}{ Age $(M=41.39 \pm S D=13.77, M d=40.0 \pm I Q R=19, M i n .=16, M a x .=78)$} \\
\hline Less than 20 & $8(66.7)$ & $4(33.3)$ & $12(4.1)$ \\
\hline 21 to 30 & $47(73.4)$ & $17(26.6)$ & $64(21.8)$ \\
\hline 31 to 40 & $45(65.2)$ & $24(34.8)$ & $69(23.5)$ \\
\hline 41 to 50 & $58(73 . .4)$ & $21(26.6)$ & $79(27.0)$ \\
\hline 51or above & $55(79.7)$ & $14(20.3)$ & $69(23.5)$ \\
\hline \multicolumn{4}{|c|}{ Marital Status } \\
\hline Single & $59(75.6)$ & $19(24.4)$ & $78(25.6)$ \\
\hline Married & $154(71.3)$ & $62(28.7)$ & $216(70.8)$ \\
\hline Divorced & $5(45.5)$ & $6(54.5)$ & $11(3.6)$ \\
\hline \multicolumn{4}{|c|}{ Occupation } \\
\hline Government employee & $94(79.0)$ & $25(21.0)$ & $119(39.0)$ \\
\hline Unemployed & $36(43.9)$ & $46(56.1)$ & $82(26.9)$ \\
\hline Private workers & $75(89.3)$ & $9(10.7)$ & $84(27.5)$ \\
\hline Students & $13(65.0)$ & $7(35.0)$ & $20(6.6)$ \\
\hline \multicolumn{4}{|c|}{ Zoba } \\
\hline Anseba & $11(64.7)$ & $6(35.3)$ & $17(5.6)$ \\
\hline Debub & $43(66.2)$ & $22(33.8)$ & $65(21.3)$ \\
\hline Gash Barka & $32(72.7)$ & $12(27.3)$ & $44(14.4)$ \\
\hline Maekel & $110(72.4)$ & $42(27.6)$ & $154(49.8)$ \\
\hline Semienawi Keiyh Bahri & $14(82.4)$ & $3(17.6)$ & $17(5.6)$ \\
\hline Debubawi Keiyh Bahri & $8(80.0)$ & $2(20.0)$ & $10(3.3)$ \\
\hline \multicolumn{4}{|c|}{ Hospital } \\
\hline National Health Laboratory & $152(72.2)$ & $50(24.8)$ & $202(66.2)$ \\
\hline Orotta Hospital & $46(63.9)$ & $26(36.1)$ & $72(23.6)$ \\
\hline Halibet Hospital & $13(68.4)$ & $6(31.6)$ & $19(6.2)$ \\
\hline Sembel Hospital & $7(58.3)$ & $5(41.7)$ & $12(3.9)$ \\
\hline Total & $218(71.5 \%)$ & $87(28.5 \%)$ & $305(100 \%)$ \\
\hline
\end{tabular}

M: Mean; SD: Standard deviation; Md: Median; IQR: Interquartile Range; Min.: Minimum; Max.: Maximum

*Percentage is computed from the row total, ${ }^{* *}$ Percentage is computed from total liver patients.

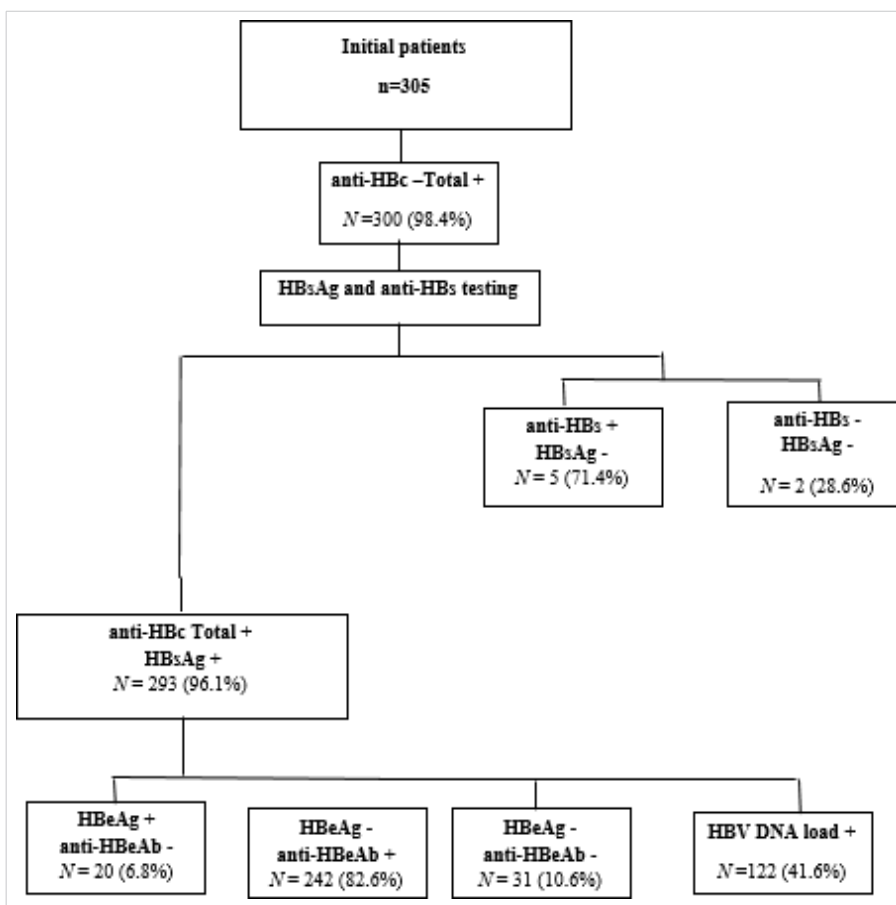

Figure 1: Study participant's distribution flowchart through hepatitis B virus seromarkers. 
difference in the age categories of $\mathrm{HBeAg}$ positive patients compared with HBeAg negative patients $(p=0.362)$. Anti-HBe was significantly more frequent in $\mathrm{HBeAg}$-negative patients compared with HBeAg-positive subjects ( $p$ value $\leq 0.001$ ).

Hence, we started with $305 \mathrm{HBsAg}$ patients by screening their serum for anti-HBc (total) seromarker, 5 were excluded because they tested negative and include who test positive for further tested for both HBsAg and anti-HBs using ELISA, because it is the only available method to confirm the HBsAg positivity patients and the chronicity phase (anti-HBc total $\mathrm{Ab}$ positive and HBsAg positive), or the patients with natural immunity (HBsAg negative, anti-HBc (total) Ab and anti-HBs $\mathrm{Ab}$ positive) or determine who recovered from previous $\mathrm{HBV}$ infection with anti-HBs Ab clearance (HBsAg negative, anti$\mathrm{HBc}$ total positive without anti-HBs $\mathrm{Ab}$ ).

\section{Biochemistry}

According the cut-off of normal value for AST and ALT below $40 \mathrm{U} / \mathrm{L}$, more than $90 \%$ of the HBV patients had normal AST and a similar percentage of normal ALT level as shown in table 2 . The levels in males and females were similar.

As HBeAg is a sign of active liver disease, liver transaminases were specifically analyzed according to $\mathrm{HBeAg}$. Out of $20 \mathrm{HBeAg}$-positive patients, 15 (75.0\%) had raised ALT and $5(25.0 \%)$ had normal ALT levels. In case of $273 \mathrm{HBeAg-}$ negative patients $29(10.6 \%)$ were with elevated ALT level and 244 (89.4\%) were with normal ALT level (Table 3). There was statistically significant difference in the rate of elevated ALT levels between HBeAg positive patients and HBeAg negative patients $(p$ value $=0.001)$.

Table 2: Percentage and distribution of positive HBV markers, Liver aminotransferases and viral load among HBV infected patients by gender.

\begin{tabular}{|c|c|c|c|}
\hline \multirow{2}{*}{ Variable } & \multirow{2}{*}{ Total $n(\%)$} & \multicolumn{2}{|c|}{ Gender } \\
\hline & & Male $n(\%)$ & Female $\mathrm{n}(\%)$ \\
\hline \multicolumn{4}{|c|}{ HBV seromarkers -positive } \\
\hline Anti-HBc total & $300(98.4)$ & $215(70.5)$ & $85(27.9)$ \\
\hline Anti-HBsAg & $7(2.3)$ & $4(1.3)$ & $2(1.0)$ \\
\hline HBsAg & $293(97.7)$ & $213(71.1)$ & $80(26.7)$ \\
\hline Anti-HBc total positive/ HBsAg-positive & $293(96.1)$ & $213(69.8)$ & $80(26.2)$ \\
\hline HBeAg-positive/Anti-HBeAg-negative & $20(6.8)$ & $15(5.1)$ & $5(1.7)$ \\
\hline HBeAg-negative/Anti-HBeAg-positive & $242(82.6)$ & $173(59.0)$ & $69(23.5)$ \\
\hline Neither $\mathrm{HBeAg}$ nor anti-HBeAg & $31(10.6)$ & $25(8.5)$ & $6(2.0)$ \\
\hline \multicolumn{4}{|c|}{ Liver aminotransferases } \\
\hline \multicolumn{4}{|c|}{ ALT } \\
\hline Normal (<40 U/I) & $259(84.9)$ & $185(60.7)$ & $74(24.3)$ \\
\hline Elevated(>40 U/I) & $46(15.1)$ & $33(10.8)$ & $13(4.3)$ \\
\hline \multicolumn{4}{|c|}{ AST } \\
\hline Normal (<40 U/l) & $267(87.5)$ & $190(62.3)$ & 77 (25.2) \\
\hline Elevated (>40 U/I) & $38(12.5)$ & $28(9.2)$ & $10(3.3)$ \\
\hline \multicolumn{4}{|c|}{ Viral load (IU/mL) } \\
\hline$<20$ & $183(60.0)$ & $129(59.2)$ & $54(62.1)$ \\
\hline $21-2,000$ & $55(18.0)$ & $38(12.5)$ & $17(5.6)$ \\
\hline $2,001-20,000$ & $40(13.1)$ & $33(10.8)$ & $7(2.3)$ \\
\hline $20,000-200,000$ & $18(5.9)$ & $11(3.6)$ & $7(2.3)$ \\
\hline$>200,001$ & $9(3.0)$ & $7(2.3)$ & $2(0.7)$ \\
\hline
\end{tabular}

Anti-HBc: Antibody to Hepatitis B core antigen; anti-HBe: antibody to hepatitis B'e' antigen; anti-HBs: antibody to hepatitis B surface antigen; HBeAg: hepatitis B ' $e$ ' antigen; HBsAg: hepatitis B surface antigen.

All percentages are computed out of the total of liver disease patients with HBV.
Table 3: Distribution of age, liver enzymes and HBV DNA levels according to HBeAg status in the patients with positive anti-HBc (total) / HBsAg $(n=293)$.

\begin{tabular}{|c|c|c|c|}
\hline Parameters & $\begin{array}{c}\text { HBeAg-positive, } \\
n(\%)\end{array}$ & $\begin{array}{c}\text { HBeAg-negative, } \\
n(\%)\end{array}$ & $p$ value \\
\hline \multicolumn{4}{|c|}{ Age group } \\
\hline Less than 20 & $4(20.0)$ & $8(2.9)$ & \multirow[t]{5}{*}{0.003} \\
\hline 21 to 30 & $6(30.0)$ & $58(21.2)$ & \\
\hline 31 to 40 & $2(10.0)$ & $67(24.5)$ & \\
\hline 41 to 50 & $5(25.0)$ & $74(27.1)$ & \\
\hline 51 or above & $3(15.0)$ & $66(24.2)$ & \\
\hline \multicolumn{4}{|c|}{ Anti-HBe } \\
\hline Positive & $1(5.0)$ & $241(88.3)$ & \multirow[t]{2}{*}{$<0.001$} \\
\hline Negative & $19(95.0)$ & $32(11.7)$ & \\
\hline \multicolumn{4}{|c|}{ ALT level } \\
\hline Normal & $5(25.0)$ & $244(89.4)$ & \multirow[t]{2}{*}{$<0.001$} \\
\hline Elevated & $15(75.0)$ & $29(10.6)$ & \\
\hline \multicolumn{4}{|c|}{ Viral load (IU/mL) } \\
\hline$\leq 2,000$ & $8(40.0)$ & 218 (79.9) & \multirow[t]{4}{*}{$<0.001$} \\
\hline $2,001-20,000$ & $6(30.0)$ & $34(12.5)$ & \\
\hline $\begin{array}{l}20,001- \\
200,000\end{array}$ & $2(10.0)$ & $16(5.9)$ & \\
\hline$>200,001$ & $4(20.0)$ & $5(1.8)$ & \\
\hline
\end{tabular}

\section{HBV viral load}

Of 293 anti-HBc total positive/HBsAg-positive patients, $122(41.6 \%)$ were detected to have HBV viral load more than $20 \mathrm{IU} / \mathrm{ml}, 55$ (18\%) patients had HBV viral load between 21 to $2000 \mathrm{IU} / \mathrm{ml}, 40$ (13.1\%) had HBV viral load between 2001 and 20,000 IU/ml, 18 (5.9\%) had HBV viral load between 20,000 and 200,000 , while $9(3 \%)$ had values $>200,001$. The Overall high-level viral replication with HBV DNA exceeding 2,000 IU/ $\mathrm{mL}$ was detected in 67 (22.86\%) patients.

The relationship between HBV DNA viral load levels and HBeAg status among patients. Table 3 shows slow replicative activity of $\mathrm{HBV}$ viral load $(\leq 2,000 \mathrm{IU} / \mathrm{ml})$ occurred more frequently in HBeAg-negative patients [218 (79.9\%)] than in HBeAg-positive patients [8 (40.0\%)]. HBV DNA replication between 20,001 and 200,000 and levels > 200,000 IU/mL were more frequently detected in HBeAg- positive patients (10.0\% and $20.0 \%$ ) compared with HBeAg- negative patients (5.9\% and $1.8 \%$ ), respectively. Subsequently, there was a statistically significant difference between HBV DNA levels of HBeAg positive patients in comparison to $\mathrm{HBeAg}$ negative patients ( $p$ value $<0.001)$.

\section{Discussion}

Eritrea is an east African multi-ethnic country surrounded by HBV hyperendemic countries. Like in many of sub-Saharan African countries, the serological profile of HBV infection in Eritrea have not been well known and confirmed [1,14]. The dynamics of HBV infection range according to clinical manifestation of the patients from acute infection stage, chronic inactive carrier state, and a chronic progressive liver disease, culminating in liver cirrhosis (LC) and hepatocellular carcinoma (HCC) [17]. Due to limited and high cost of molecular testing, fewer studies are available evaluating both HBV seromarkers and quantification of HBV DNA in infected 
population $[1,18]$. Hence, the current study was conducted to evaluate the serological and virological status of HBV infected patients in Eritrea.

Hepatitis B virus infection is known to affect millions of people worldwide cutting across gender and all age groups [19]. Patients who exhibited HBsAg positive serology were included in this study. The patients' mean age was 41.39 ( $S D=13.77$ ) years ranging from 16 to 78 years old. This was congruent to a study by Souza, et al. 2015 and Islam, et al. [20]. Our study showed a preponderance of male participants who constituted $71.5 \%$ of the cases compared to $28.5 \%$ females. This distribution is in agreement with an Ethiopian study that reported the prevalence of HBV infection being higher in males (38\%) than females (31.8\%) [21], indicating male predominance and underlying higher prevalence of HBV among males in Africa. Most of the participants were adults above 20 years of age with similar distribution of the age groups. This conforms to the bulk of the literature that shows high prevalence of HBV in both middle-and older aged adults, as compared to young adults. In accordance, Elmukashf, et al. (2012) reported most of the patients (58.4\%) were between the age group 30-49 years [22].

The patterns of HBV serological markers play an essential role in characterizing the disease phases and determining requirement for antiviral therapy. In endemic regions of HBV infection estimated that up to one-third of the population have evidence of previous infection with HBV as indicated by an isolated anti-HBc serology [9]. Our findings show high percentage $(96.1 \%)$ of patients in chronicity phase who test positive for both anti-HBc total and HBsAg, compared to low perseverance $(2.3 \%)$ of patients who recovered from previous exposure to HBV infection or natural immunity in consistent with a previous study in Eritrea by Fessehaye, et al. [14]. This implies the need to implement and enforce vaccination programs among high and low risk groups [23-25].

This study documented a higher proportion HBeAg negative (93.2\%) compared to HBeAg positive (6.8\%) patients in congruence with studies such as conducted by Di Bisceglie, et al. [26]. Four out of five our patients were in a low replicative phase of chronic hepatitis B characterized by HBeAg-negative status, detection of $\mathrm{HBe}$ antibodies (anti-HBe), and DNA concentration below $2000 \mathrm{IU} / \mathrm{mL}$ with normal ALT, who are considered as chronic inactive carriers in similar proportion to what some studies have shown [27-30]. The determination of high percentage of HBeAg negative patients with low HBV viral loads in our study implies that most of the HBV patients are not eligible for antiviral therapy due to minimal or absent liver injury with low risk of disease progression [12].

We found high prevalence of HBeAg-negative hepatitis patients with high-level active HBV replication despite detectable anti-HBe antibodies. This finding is similar to studies that have shown HBeAg-negative hepatitis as the common form of chronic hepatitis B virus associated liver disease progression and activity of HBV viral mutations in Asia and sub-Saharan Africa [18,31,32].

To the best of our knowledge, this study is the first of its kind in Eritrea to describe the serological and virological markers among patients with chronic hepatitis B infection. Nevertheless, some limitations in the current study are worth mentioning. Being a cross-sectional study without follow-up of the patients, it is difficult to have an accurate picture of the natural history of the infection. The fact that it is laboratorybased lacks important clinical data for categorizing the patients according to their status of liver disease using ultrasonography or liver biopsy.

\section{Conclusion}

This study demonstrated the predominance of HBeAgnegative infection and low replication of HBV with significantly low viral loads among HBV patients in Eritrea. Our study also shows that most patients had chronic hepatitis B infection with normal liver transaminase levels in the absence of laboratory sign of hepatitis. Our findings are expected to provide a basis for an informed planning of national chronic hepatitis B treatment guidelines. A large-scale population or clinical cohort study in the future is recommended to fully explore the natural history and phases of hepatitis B infection among Eritrean patients.

\section{Availability of data and materials}

All data and materials described in the manuscript are available.

\section{Funding}

This research did not receive any grant from funding agencies in the public, commercial, or not-for-profit sectors.

\section{Authors' contributions}

Mohammed Elfatih Hamida, Saud Mohammed Raja, Yemane Seyoum, Isam Mohammed Elkhidir and Freweini Tekle conceived and de- signed the study. Mohammed Elfatih Hamida, Saud Mohammed Raja and Freweini Tekle analyzed the data. Mohammed Elfatih Hamida, Saud Mohammed Raja and Yemane Seyoum revised the paper. Mohammed Elfatih Hamida and Saud Mohammed Raja wrote the manuscript. All authors read and approved the final manuscript.

\section{Ethics approval and consent to participate}

Ethical approval for this study was obtained from ethical research committee board of Orotta College of Medicine and Health Sciences (OCMHS) and Ministry of Health state of Eritrea (MoH). A written informed consent was obtained from each study participant before collecting the demographic and clinical data. 


\section{Acknowledgement}

We would like to thanks; the members of the Immunoserology department at Eritrean National Health Laboratory (ENHL), and Eritrean National Council for Higher Education.

\section{References}

1. WHO. Global hepatitis report 2017. 2017: World Health Organization.

2. Kramvis A, Kew MC. Epidemiology of hepatitis B virus in Africa, its genotypes and clinical associations of genotypes. Hepatol Res. 2007. 37: S9-S19.

PubMed: https://pubmed.ncbi.nlm.nih.gov/17627641

3. Bogler Y, Wong RJ, Gish RG. Epidemiology and Natural History of Chronic Hepatitis B Virus Infection, in Hepatitis B Virus and Liver Disease. Springer. 2018; 63-89.

4. Lavanchy D, Kane M. Global epidemiology of hepatitis B virus infection, in Hepatitis B virus in human diseases. Springer. 2016; 187-203.

5. Yang HC, Shih YF, Liu CJ. Viral factors affecting the clinical outcomes of chronic hepatitis B. J Infect Dis. 2017; 216(suppl_8): S757-S764.

6. European Association for the Study of the Liver. EASL clinical practice guidelines: management of chronic hepatitis B virus infection. J Hepatol. 2012; 57: 167-185.

PubMed: https://pubmed.ncbi.nlm.nih.gov/22436845/

7. Terrault NA, Bzowej NH, Chang KM, Hwang JP, Jonas MM, et al. A ASLD guidelines for treatment of chronic hepatitis B. Hepatology. 2016; 63: 261-283.

PubMed: https://www.ncbi.nlm.nih.gov/pmc/articles/PMC5987259/

8. Croagh CM, Lubel JS. Natural history of chronic hepatitis B: phases in a complex relationship. World J Gastroenterol. WJG. 2014; 20: 10395. PubMed: https://pubmed.ncbi.nlm.nih.gov/25132755/

9. Lau GK. How do we handle the anti-HBc positive patient? (in highly endemic settings). Clin Liver Dis. 2015; 5: 29-31.

PubMed: https://www.ncbi.nlm.nih.gov/pmc/articles/PMC6490450/

10. Liu J, Yang H, Lee M, Lu S, Jen C, et al. Spontaneous seroclearance of hepatitis B seromarkers and subsequent risk of hepatocellular carcinoma. Gut. 2014; 63: 1648-1657.

PubMed: https://pubmed.ncbi.nlm.nih.gov/24225939

11. Kirk GD, Lesi OA, Mendy M, Akano AO, Sam O, et al. The Gambia Liver Cancer Study: Infection with hepatitis $B$ and $C$ and the risk of hepatocellular carcinoma in West Africa. Hepatology. 2004; 39: 211-219. PubMed: https://pubmed.ncbi.nlm.nih.gov/14752840

12. WHO. Guidelines for the prevention care and treatment of persons with chronic hepatitis B infection: Mar-15. 2015: World Health Organization.

13. Li Q, Ren X, Lu C, Li W, Huang Y, et al. Evaluation of APRI and FIB4 for noninvasive assessment of significant fibrosis and cirrhosis in $\mathrm{HBeAg}$-negative $\mathrm{CHB}$ patients with $\mathrm{ALT} \leq 2 \mathrm{ULN}$ : A retrospective cohort study. Medicine. 2017; 96: e6336.

PubMed: https://pubmed.ncbi.nlm.nih.gov/28328813/

14. Fessehaye ND, Berhane NA, Ahimed H. Prevalence of hepatitis B virus infection and associated seromarkers among pregnant women in Eritrea. J Human Virol Retrovirol. 2018; 6: 00191.

15. Fessehaye N, Naik D, Fessehaye T. Transfusion transmitted infections-A retrospective analysis from the National Blood Transfusion Service in Eritrea. Pan African Med J. 2011; 9; 40.

PubMed: https://www.ncbi.nlm.nih.gov/pubmed/22145069

16. Papatheodoridis GV, Manolakopoulos S, Liaw Y, Lok A. Follow-up and indications for liver biopsy in $\mathrm{HBeAg}$-negative chronic hepatitis $\mathrm{B}$ virus infection with persistently normal ALT: a systematic review. J Hepatol. 2012; 57: 196-202.

PubMed: https://pubmed.ncbi.nlm.nih.gov/22450396/

17. Merican I. Chronic hepatitis B virus infection in Asian countries. J Gastroenterol Hepatol. 2000. 15: 1356-1361.

18. Lesi O. Serological and virological markers of nigerian patients with hepatitis B infection. Niger J Clini Practice, 2019; 22: 534.

19. Baig S. Gender disparity in infections of Hepatitis B virus. J Coll Physicians Surg Pak, 2009. 19: 598-600.

PubMed: https://pubmed.ncbi.nlm.nih.gov/19728952/

20. Souza ND. Assessment of health-related quality of life and related factors in patients with chronic liver disease. Bra J Infect Dis. 2015. 19: $590-595$.

21. Abdelmenan S, Banes A, Berhane Y, Abebe M, Wandall JH. Etiology of Chronic Liver Disease in Ethiopia: A Case Control Study with Special Reference to Viral Hepatitis and Alcohol. EC Gastroenterol Digestive Sys. 2018; 5: 120-128.

PubMed: https://www.ncbi.nlm.nih.gov/pmc/articles/PMC6402780/

22. Elmukashfi TA, Ibrahim OA, Elkhidir IM, Bashir AA, Elkarim MAA Socio-demographic characteristics of health care workers and hepatitis $B$ virus (HBV) infection in public teaching hospitals in Khartoum State, Sudan. Glob J Health Sci. 2012; 4: 37-41.

PubMed: https://www.ncbi.nlm.nih.gov/pmc/articles/PMC4776931/

23. Hoofnagle J, Gerety R, Barker L. Antibody to hepatitis-B-virus core in man. The Lancet. 1973; 302: 869-873.

24. Hollinger FB. Hepatitis $B$ virus infection and transfusion medicine: science and the occult. Transfusion. 2008; 48: 1001-1026. PubMed: https://pubmed.ncbi.nlm.nih.gov/18454738/

25. Liang X. Reprint of: Epidemiological serosurvey of Hepatitis B in China-Declining HBV prevalence due to Hepatitis B vaccination. Vaccine. 2013; 31: J21-J28.

26. Di Bisceglie AM, Lombardero M, Teckman J, Roberts L, Janssen HLA, et al. Determination of hepatitis B phenotype using biochemical and serological markers. J Viral Hepatitis. 2017; 24: 320-329. PubMed: https://www.ncbi.nlm.nih.gov/pubmed/27917600

27. Terrault N. American Association for the Study of Liver D. AASLD guidelines for treatment of chronic hepatitis B. Hepatology. 2016; 63 : 261-283.

28. Roos R. A cross sectional study of HBeAg negative chronic hepatitis B virus infection in Cape Town, South Africa: P067. J Viral Hepatitis. 2015; 22: 53-54.

29. Ivón CFM, Zaily DG, Leda Patricia DCE, Enrique GG, Enrique AS, et al. Current Condition of Chronic Hepatitis B Virus Infection in Cuban Adults. Curr Ther Res Clin Exp. 2017; 85: 15-19. PubMed: https://pubmed.ncbi.nlm.nih.gov/29158854/

30. Tufon KA, Anong DN, Meriki HD, Georges, TD, Maurice, M, et al. Characterization and assessment of HBV chronically infected patients: Identification of those eligible for treatment in the South West region of Cameroon. PloS one. 2018; 13: e0203312. PubMed: https://www.ncbi.nlm.nih.gov/pmc/articles/PMC6124766/

31. Hadziyannis SJ, Vassilopoulos D. Hepatitis B e antigen-negative chronic hepatitis B. Hepatology. 2001; 34: 617-624.

PubMed: https://www.ncbi.nlm.nih.gov/pubmed/11584355

32. Iregbu K, Nwajiobi-Princewill PI. Viral Load Pattern Among Hepatitis B Surface Antigen-positive Patients: Laboratory Perspective and Implications for Therapy. Ann Med Health Sci Res. 2016; 6: 95-99. PubMed: https://www.ncbi.nlm.nih.gov/pmc/articles/PMC4866374/ 